\title{
A responsible proposal for Italian seafood consumers'
}

\author{
Giosuè $C^{1}$, Gancitano $V^{2}$, Sprovieri $\mathrm{M}^{1}$, Bono $\mathrm{G}^{2}$, Vitale $\mathrm{S}^{3}$
}

\begin{abstract}
:
Sustainable seafood consumption is a very intricate process, where different factors in diverse ways can influence the consumer's behaviour. One of them is the knowledge on aspects related to seafood consumption and resource exploitation. Moreover, the sustainable criteria aren't always clear and opportunely updated for consumers, both under the form of eco-labels and seafood guides. In this context, the aim of the paper was to easily provide buying suggestions based on scientific sustainable criteria, guiding consumers toward to responsible seafood consumption. Data collected during the framework of the study on consumers' perception for eco-labeled Mediterranean anchovy, were adopted as case-study for the most common species sold in fish shop. Each species of the list of seafood preferred by consumers was synoptically related to 4 items, regarding the healthy status of the marine resource, the legal landing size, as well as biological aspects related to reproductive features. The table obtained was summarized and simplified for consumer use, realizing a friendly picture with figure/graphic, where possible. The implementation of the considered sustainable criteria provides useful suggestion orienting consumer toward to responsible seafood consumption, although a compromise among social, economic and environmental sustainability, consumer's requests and his awareness needs to be improved.
\end{abstract}

Keywords: Sustainable criteria, Seafood, consumers' guide

\section{Introduction}

In the last years, several studies investigated worldwide the consumer's awareness and willingness to pay for sustainable seafood (Johnston et al., 2001; Johnston \& Roheim, 2006; Erwann, 2009; Goyert et al., 2010; Masahiko, 2010; Roheim et al., 2011; Davidson et al., 2012; Xu et al., 2012; Fernández-Polanco et al., 2013; Sogn-Grundvåg et al., 2013; Uchida et al., 2014; Fonner \& Sylvia, 2015; Blomquist et al., 2015; Salladarré et al., 2016, McClenachan et al., 2016; Bronnmann \& Asche, 2016; Zhou et al., 2016; Rickertsen et al., 2017; Sun et al., 2017; Vitale et al., 2017), showing as these aspects may not directly translated into sustainable consumer behavior (World Business Council for Sustainable Development, 2008; Clonan et al., 2011; Nguyen et al., 2010; Brécard et al., 2012; Richter et al., 2017). Indeed, the sustainable seafood consumption is a very intricate process, where different factors (intentions, attitudes, social norms, trust, knowledge, habits, situational and socioeconomic conditions) and their interactions can influence the consumer's behavior (fig 1; Richter et al., 2017). 


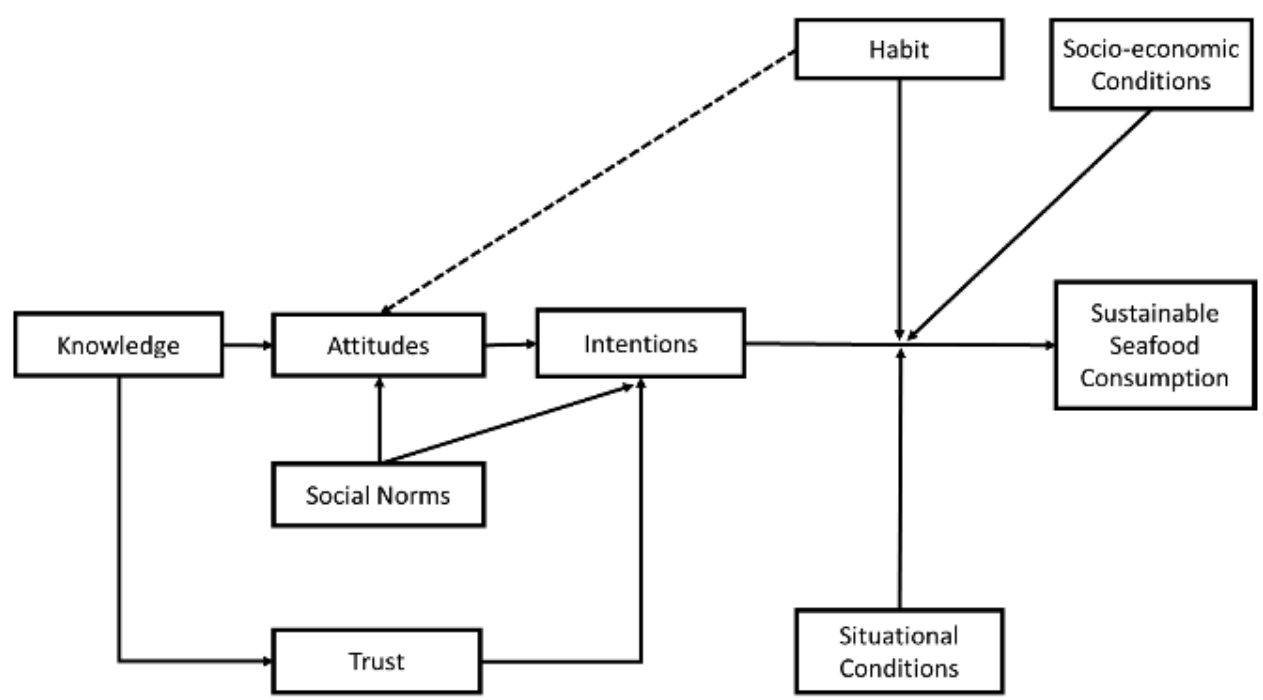

Figure 1. Model of Sustainable Seafood Consumption by Richter et al. 2017

Therefore, all these aspects contribute to make difficult the transfer and assimilation of the concepts on sustainable seafood consumption into consumers. Considering the "knowledge", the criteria for a sustainable consumption are not always clear for consumers. Indeed, among diverse sectors, the sustainable criteria constantly change due to different factors (e.g. seasonal variations, climate change, technical improvements, governmental regulations, and market developments), and the consumers have often limited access to up-dated sustainability criteria during the purchase process (Richter et al., 2017).

Consequently, consumers can only relying on seafood label and seafood guide trying to overtake these gaps on sustainable seafood consumption. Both, seafood label and seafood guide present advantage and disadvantage. The eco-label, in fact, can enclose different attributes based on the sustainability, and it is able to make the product easily recognizable. Consequently, the consumers showed greater awareness and different willingness to pay for eco - labeled seafood in function of the species, the countries, brand, etc. (Vitale et al., 2017). In the same time, some studies showed the ecolabel limits, mainly due to the difficulties of the consumers in the understanding the real meaning of eco-label (Brécard et al., 2012; Pérez-Ramìrez et al., 2015), which is often associated to other concepts, such as health and food safety concerns (Nguyen et al., 2010; Brécard et al., 2012; Gutierrez \& Thornton, 2014). The seafood guides are referred to particular country or region, and support the consumers offering some information on marine ecosystems, sustainable use of marine resources and consumer responsibility. The guides present the list of seafood categorized on up-date scientific evidence, and the species are often reported following the traffic light system, using green, yellow and red for recommended, critical and avoid species, respectively. In this sense the seafood guides are useful for consumers, but often they require time to be used (Richter et al. 2017). 
These aspects show how it is necessary to consider the consumer's psychology and the potential levers to be pulled to motivate consumers for sustainable purchase decisions (Richter et al., 2017), including the effort of the scientific community to increase its capacity to transfer the current knowledge on the health status of the marine ecosystems. Moreover, the policy maker, together with the other stakeholders, should assess sustainable policy directed towards consumers, addressing appropriate incentive useful to insure a long-term management of fisheries. In this scenario, the role of fisherman should be fundamental, becoming the main actor and not only the main benefactor, supporting most of the costs, as often happening (Gudmundsson \& Wessells, 2000; United Nations Environment Programme, 2005; Roheim et al., 2011; Blomquist et al., 2015). Seems clear that, for a sustainable seafood consumption, all actions should pursue the main goal to determine an appropriate dynamic equilibrium among biological-ecological issues, socio-economic aspects and governance, to insure mainly these commons to the next generations.

In this context, the goal of this contribute is to attempt suggesting on some potential sustainable criteria, that could be useful to guide the consumers toward a responsible seafood consumption in the Mediterranean basin. In this regard, data collected during the framework of the study on consumers' perception for eco-labeled Mediterranean anchovy, were adopted as case-study for the most common species sold in fish shop.

\section{Material and methods}

A study on the Italian awareness and their willingness to pay for Eco-Labeled Mediterranean anchovy was carried out, interviewing consumers at Auchan fish shop. The sample of respondents was selected in accordance with the main socio-demographic determinants of fish consumption among European consumers (e.g. Pieniak et al., 2007). The survey included, over the usual socio demographic variables, questions on fishing knowledge, factors influencing seafood purchase, awareness for eco-label seafood, etc. (results in publication). Factors, like price, origin of the product, freshness, etc., were considered to define an influencing rank on seafood purchase. Moreover, a list of Mediterranean seafood species according to the Italian consumer's preference was redacted.

The considered sustainable criteria for a responsible seafood consumption were: i) the healthy status of the marine resource (Abella et al., 2011; Cardinale \& Osio, 2014; International Commission for the Conservation of Atlantic Tuna, 2016; Simmonds et al., 2017), ii) the minimum sizes of marine organisms (Reg. EC 1967/2006) and iii) the reproductive features by species (Sartor et al., 2017).

In particular, the evaluation of healthy status of the marine resource referred to the current evaluations on stock assessment $(S A)$ of the investigated species. It is worth to highlight as "Stock assessment involves the use of various statistical and mathematical calculations to make quantitative predictions about the reactions of fish populations to alternative management choices" (Hilborn \& Walters, 1992). It tells us if the abundance of a stock is below or above a given target point and by doing so lets us know whether the stock is overexploited or not; it also tells us if a catch level will maintain or change the abundance of the stock. In 
the present study the following criteria

(http://www.fao.org/gfcm/meetings/info/it/c/1040665/) was used to assess the level of overfishing status:

- If $F c / F 0.1$ is below or equal to 1.33 the stock is in Low Overfishing (OL);

- If the $F c / F 0.1$ is between 1.33 and 1.66 the stock is in Intermediate Overfishing $(O I)$;

- If the $F_{c} / F 0.1$ is equal or above to 1.66 the stock is in High Overfishing $(O H)$,

where $F_{c}$ indicates the current level of fishing mortality and $F 0.1$ is a target reference point for the fishing mortality.

The minimum sizes of marine organisms (MS) is a value of the size assigned to marine organisms to improve their exploitation and to set standards to build management system for fisheries. A marine organism, which is smaller than minimum sizes reported in Annex III of the Reg. EC 1967/2006, shall not be caught, retained on board, transshipped, landed, transferred, stored, sold, displayed or offered for sale.

The reproductive features considered both the $L_{50 \%} / W_{50 \%}$ and the reproductive period (RP) by species. The $L_{50 \%} / W_{50 \%}$ is the length/weight at which $50 \%$ of the species of a given sex (normally females) are considered to be mature (Potts \& Wootton, 1989). The $R P$ indicates the time in which the species spawn. In particular, most of the species exhibit seasonal cycle in the production of gametes. The expulsion of gametes from the body into the surrounding water is called 'spawning' resulting in fertilization. The spawning depends on the availability of certain crucial environmental factors like temperature, photoperiod, etc.. (Potts \& Wootton, 1989).

The available literature was collected for each issue related with the selected criteria. The data collected were used to realize: 1) a synoptic table of the four items $(S A$, $L_{50 \%} / W_{50 \%}, M S$ and $R P$ ) chosen among the criteria and 2) a friendly table summarizing the four items by picture/graphic, using a risk-adverse approach. In particular, the friendly table aggregates the data under the following manner:

- $\quad L_{50 \%-M S}$, comparing the values collected, independently from the sex, only the highest one was reported;

- $R P$, if the information accomplished reproductive peaks, these periods were indicated using red bars at the correspondent months. If the information provides different peaks for different areas, only the common peaks were reported. If the information did not report peaks and the reproductive period was equal or lower than 4 months, only the middle period was assumed likely "peak" and reported using yellow bars. Other cases were not reported.

- $\quad S A$, it was reported a rough average of the level of exploitation, using a green, a yellow and a red smiley from happy to sad looking, to indicate the healthy status of the resources (happy-green: low overfishing; indifferent-yellow: intermediate overfishing; sad-red: high overfishing). 


\section{Results}

A total of 560 consumers were interviewed, equally distributed by sex. The main factors declared to be important during the seafood purchase were the freshness, the origin and the price, while the knowledge about the state of exploitation of the species was the last one (figure 2).

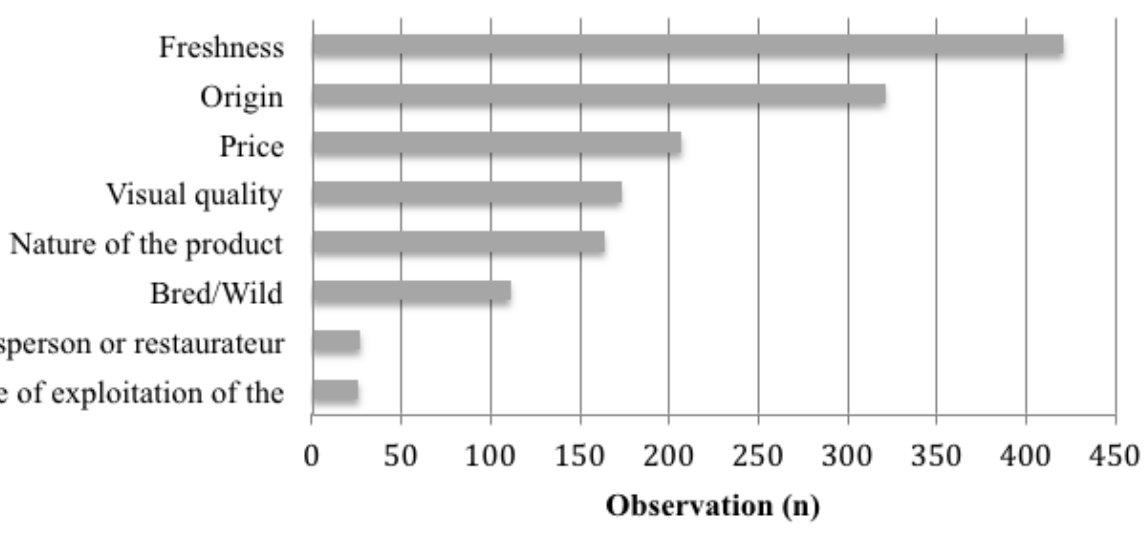

Figure 2. Principal factors considered by consumers during the fish purchase

The survey permitted to define a list of 24 seafood species commonly purchased among the Italian consumers. The higher preference was recorded for Sparus auratus (Gilthead bream) followed by Dicentrarchus labrax (European seabass), Xiphias gladius (Swordfish) and Sardina pilchardus (European pilchard), etc. (figure 3). 


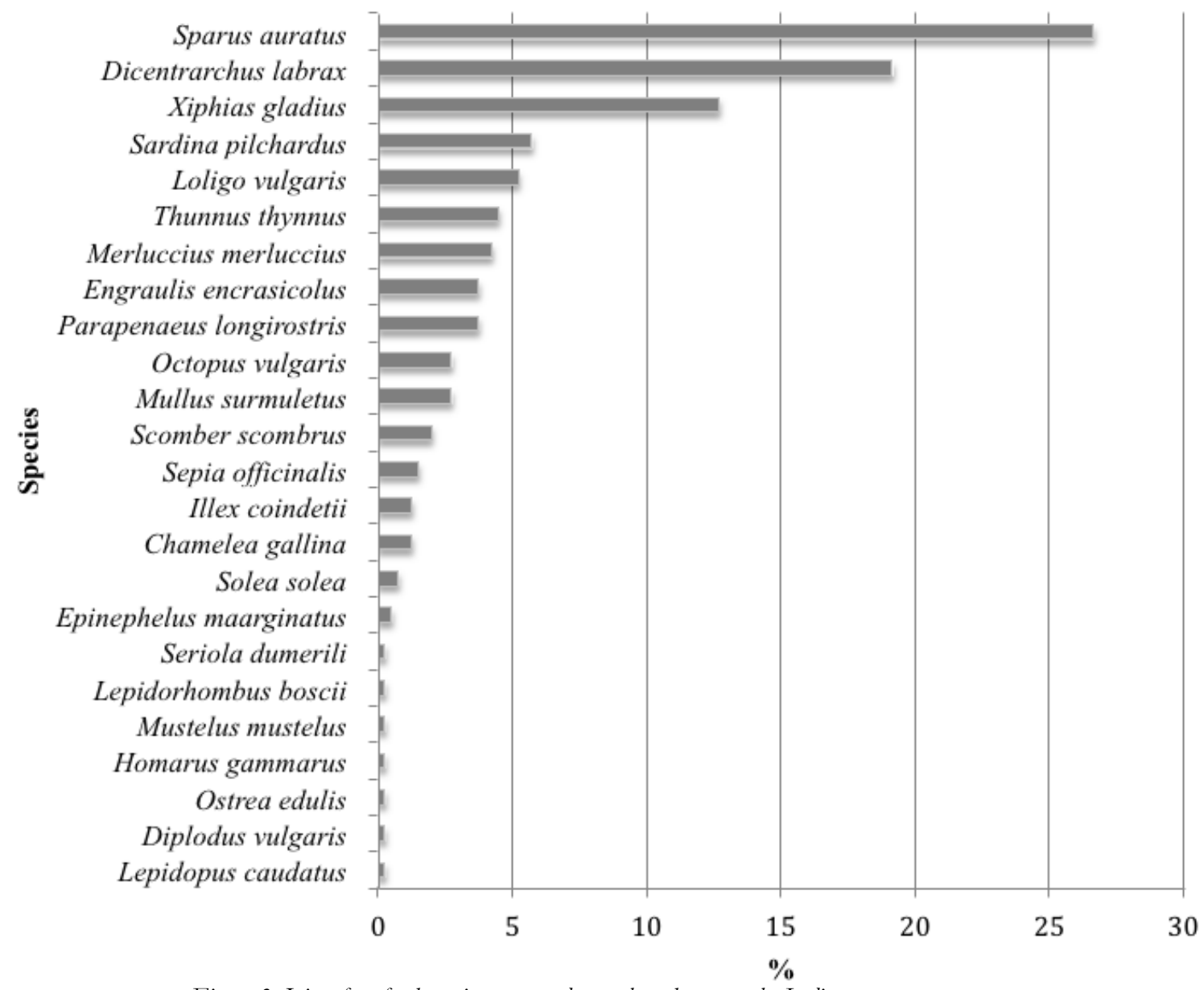

Figure 3. List of seafood species commonly purchased among the Italian consumers

Only 10 of the 24 species above reported are under evaluation by $S A$ in the Mediterranean sea. In many cases the same species was assessed $(S A)$ in different Geographical Sub Areas (GSAs), consequently more than one evaluation was reported. On the basis of the level of overfishing status $\left(F_{c} / F 0.1\right), 3$ species resulted in OH (Sparus auratus, Dicentrarchus labrax and Mullus surmuletus), 2 species in OH or OI (Xiphias gladius and Merluccius merluccius), 1 species in OI (Solea solea), 2 species in OL or OH (Sardina pilchardus, Parapenaeus longirostris), 1 species in OL or OI (Engraulis encrasicolus) and 1 species in OL (Sepia officinalis) (Appendix).

The $\mathrm{L}_{50 \%}$ or $W_{50 \%}$ was found only for 15 species. Among them, for 8 species the estimated values were reported for sex combined (Dicentrarchus labrax, Xiphias gladius, Sardina pilchardus, Thunnus thynnus, Parapenaeus longirostris, Sepia officinalis, Solea solea, Lepidorhombus boscii), while for the others the values were found by sex (Loligo vulgaris, Merluccius merluccius, Engraulis encrasicolus, Octopus vulgaris, Mullus surmuletus, Illex coindetii and Lepidopus caudatus-Appendix). 
Among the 24 species preferred by consumers, only 16 species are subjected to a MS (Sparus auratus, Dicentrarchus labrax, Xiphias gladius, Sardina pilchardus, Thunnus thynnus, Merluccius merluccius, Engraulis encrasicolus, Parapenaeus longirostris, Octopus vulgaris, Mullus surmuletus, Scomber scombrus, Chamelea gallina, Epinephelus maarginatus, Homarus gammarus, Ostrea edulis and Diplodus vulgaris) and for 9 species were found both the $L_{50 \%}$ and the $M S$ (Dicentrarchus labrax, Xiphias gladius, Sardina pilchardus, Thunnus thynnus, Merluccius merluccius, Engraulis encrasicolus, Parapenaeus longirostris, Octopus vulgaris and Mullus surmuletus Appendix). Comparing the two values, the $L_{50 \%}$ was always higher (except for Thunnus thynnus) than the $M S$, with differences that ranged from $12 \%$ (Sardina pilchardus) to $53 \%$ (Merluccius merluccius).

Taking into account the $R P$, is possible to empathize the following differences among the species:

- $\quad$ during all the year (Loligo vulgaris, Merluccius merluccius, Parapenaeus longirostris, Sepia officinalis, Illex coindetii);

- $\quad$ during all the year except winter (Engraulis encrasicolus, Lepidopus caudatus);

- during all the year except summer (Solea solea);

- during all the year with preference in spring-summer (Octopus vulgaris, Chamelea gallina);

- $\quad$ in spring (Mullus surmuletus, Ostrea edulis);

- $\quad$ in summer (Thunnus thynnus, Epinephelus maarginatus, Mustelus mustelus, Homarus gammarus);

- $\quad$ in winter (Scomber scombrus, Lepidorhombus boscii);

- late autumn (Sparus auratus);

- $\quad$ late autumn and winter (Dicentrarchus labrax, Sardina pilchardus, Diplodus vulgaris);

- late spring and summer (Xiphias gladius) (Appendix).

Only for 7 species (Dicentrarchus labrax, Xiphias gladius, Sardina pilchardus, Merluccius merluccius, Engraulis encrasicolus, Parapenaeus longirostris, Mullus surmuletus) it was possible to found complete information on all the criteria considered. No information for all the four items ( $S A, L_{50 \%} / W_{50 \%}, M S$ and $\left.R P\right)$ was found for Seriola dumerili.

Reporting the higher value between the $M S$ and $L_{50 \%}$, the "desirable" seafood size for purchase was reported for 22 species (all, except Seriola dumerili and Mustelus mustelus - table 1).

Xiphias gladius, Loligo vulgaris, Merluccius merluccius, Octopus vulgaris, Epinephelus maarginatus, Lepidorhombus boscii and Lepidopus caudatus were characterized by reproductive peaks, while Sparus auratus, Thunnus thynnus, Mullus surmuletus, Scomber scombrus, Mustelus mustelus, Homarus gammarus and Ostrea edulis by middle periods considered as "peaks"; in general, these spawning periods mainly occur in spring and summer (table 1).

The current bealthy status for the 10 species with available $S A$ information was reported on average for different GSAs, resulting 5 with a sad-red (Sparus auratus, Dicentrarchus labrax, Xiphias gladius, Merluccius merluccius and Mullus surmuletus), 4 with a indifferent-yellow (Sardina pilchardus, Engraulis encrasicolus, Parapenaeus longirostris, Solea solea) and only 1 species with a bappy-green (Sepia officinalis) smileys (table 1). 
Table 1. Friendly table of the seafood species related to the adopted sustainable criteria

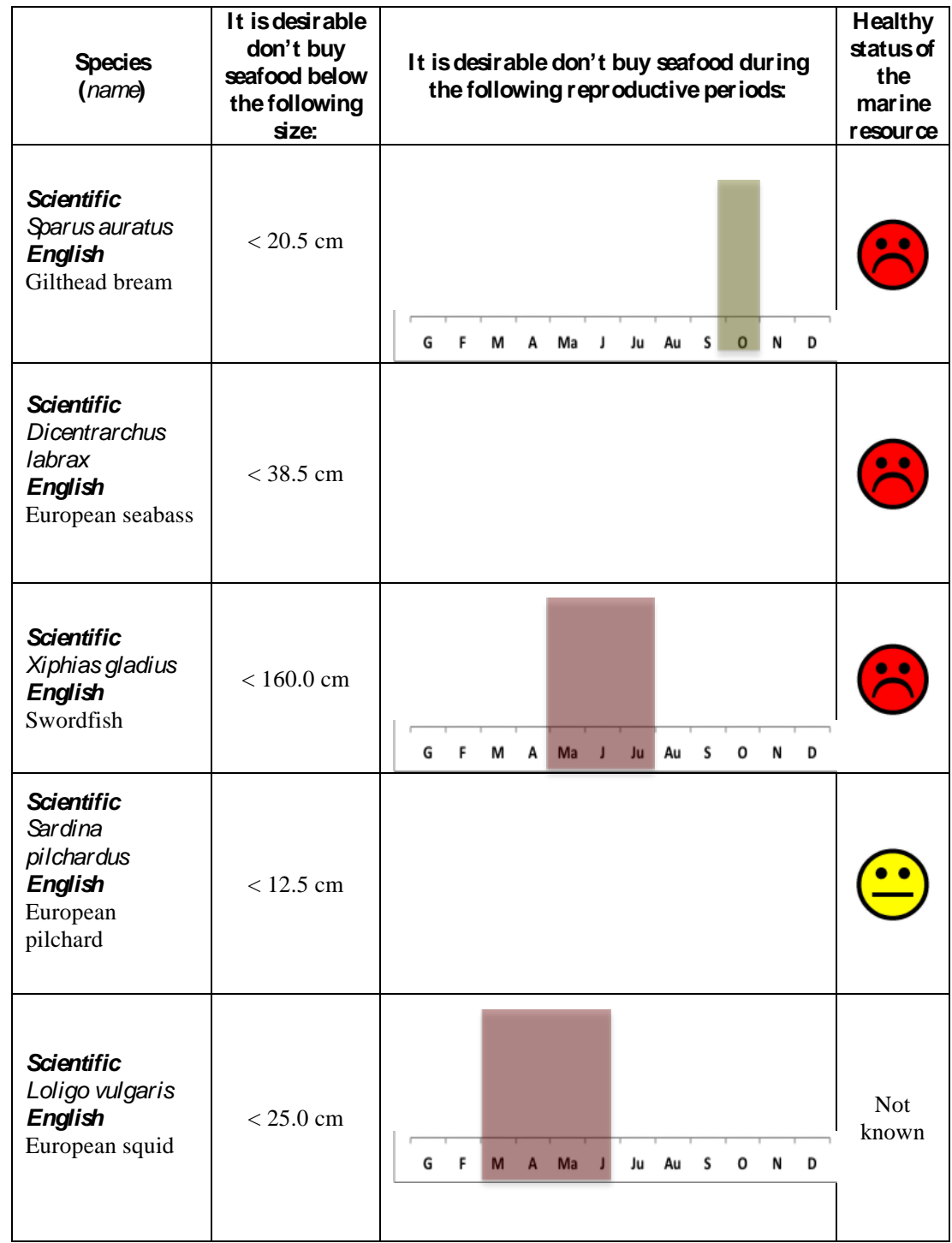




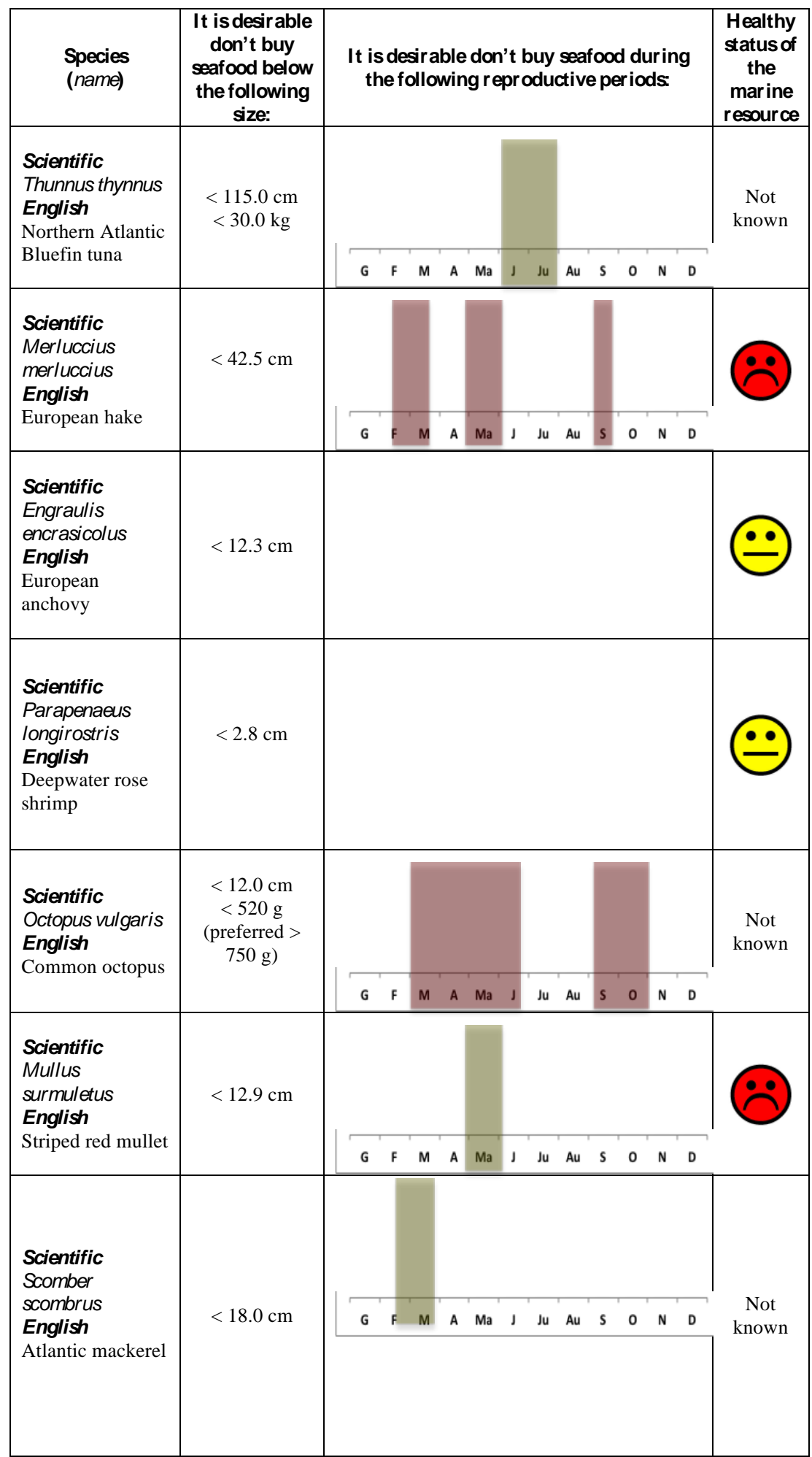




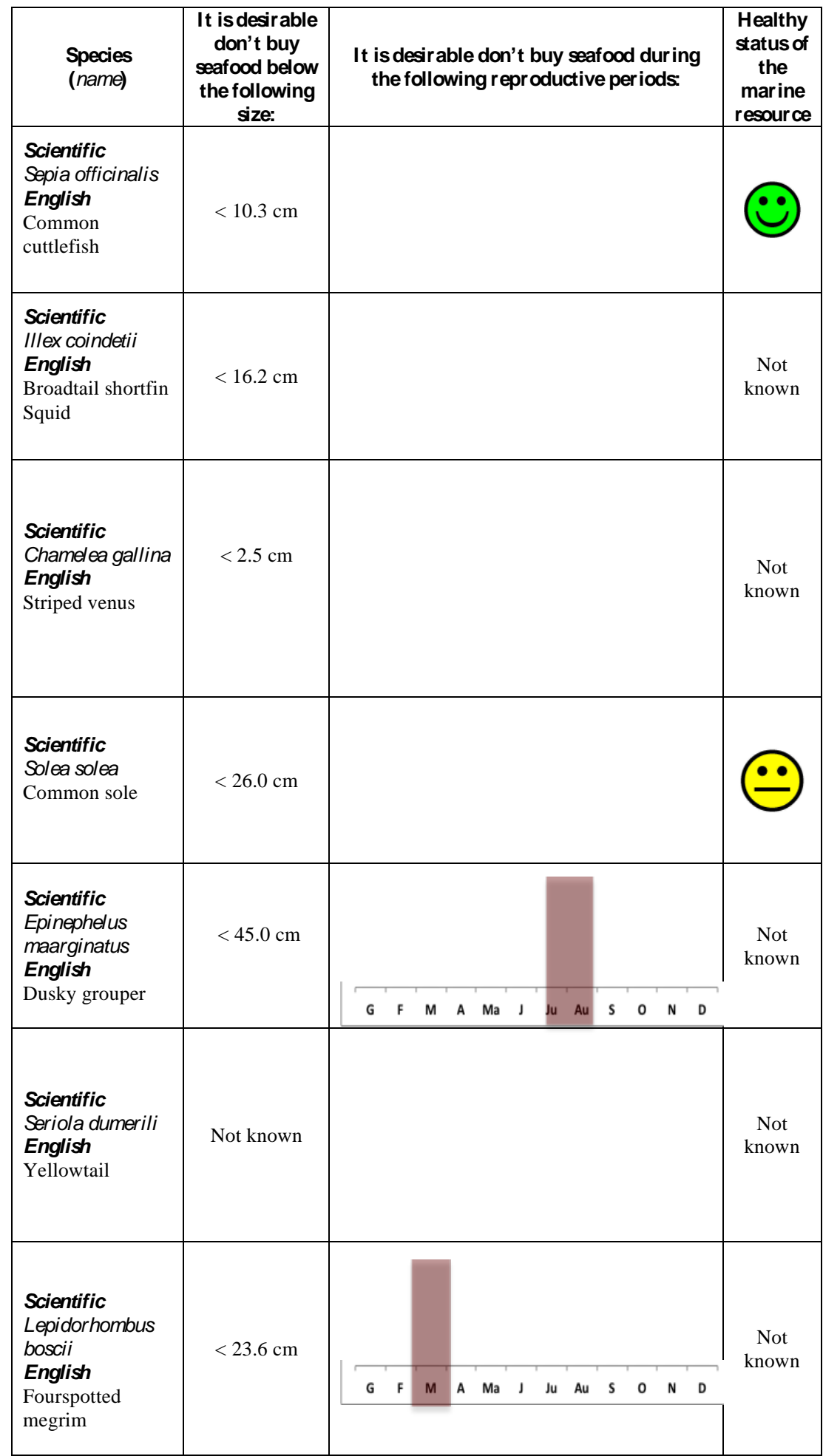




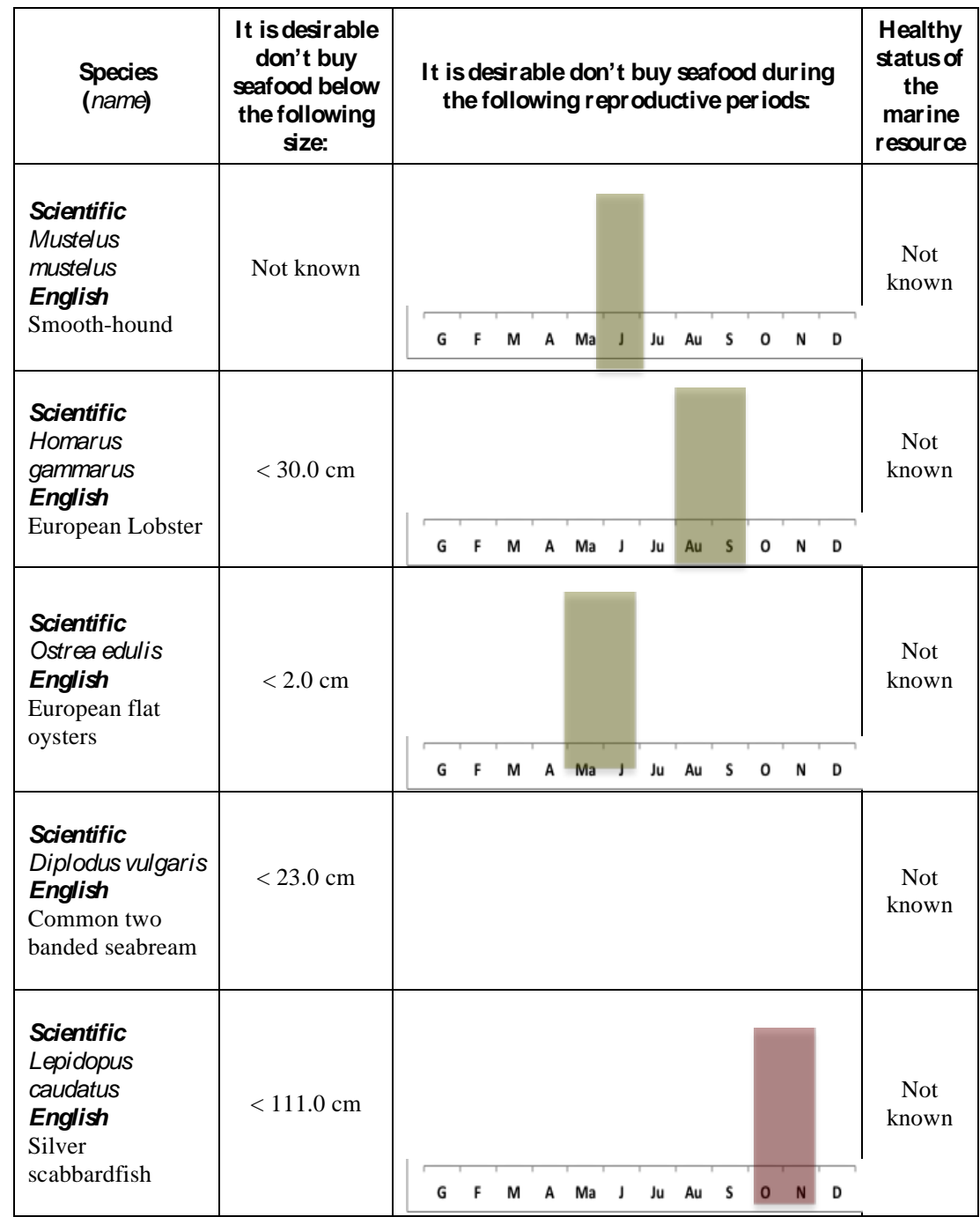

\section{Discussions}

The survey showed that consumers paid mainly attention to factors related to the quality of the product than to those affecting the exploitation of the marine resources. These results are in line with those observed in studies carried out to investigate the consumers' awareness and willingness to pay for eco-labelled seafood, showing that health and food safety concerns actually motivate the purchase of ecologically friendly food (Nguyen et al., 2010; Brécard et al., 2012; Gutierrez \& Thornton, 2014). In this direction, significant connection between the desire for ecolabeling and seafood features, especially fish quality and freshness, geo-origin of fish and 
wild versus farmed origin were observed (Jaffry et al., 2004; Brécard et al., 2009; Goyert et al., 2010; Xu et al., 2012).

In this study, the price was another important factor influencing the seafood purchase, in accordance with those found by the Istituto di Servizi per il Mercato Agricolo Alimentare (2011) and the European Market Observatory for Fisheries and Aquaculture Products (2017), in specific studies on the perception and consumption of seafood by Italian and European population, respectively. The seafood, indeed, is considered a category of product with higher price than other protein fonts, such as meat, representing a barrier that limits the purchase (Istituto di Servizi per il Mercato Agricolo Alimentare, 2011; European Market Observatory for Fisheries and Aquaculture Products, 2017).

The considered sustainable criteria for a responsible seafood consumption were i) the current healthy status of the marine resource ii) the minimum sizes of marine organisms and iii) the reproductive features by species, taking into account the $S A$, $L_{50 \%} / W_{50 \%,} M S$ and $R P$, respectively. In the specific, the $S A$ highlighted that the healthy status of the marine resources is in general not good, with high level of overexploitation. Comparing the $L_{50 \%}$ with $M S$, the $L_{50 \%}$ was always higher (except for Thunnus thynnus) than the $M S$ and, reporting the higher value between these 2 items, it was possible to indicate the "desirable" risk adverse seafood size for 22 species. Nevertheless, it is difficult to propose the "best size" considering the multispecies fisheries that characterize the Mediterranean Sea, the difficult to improve the selectivity of the fishing gears insuring, in the meantime, the profit of the fishermen and the sustainability of the marine ecosystem. Regarding the reproductive periods, the spring - summer are the seasons more interested by the spawning for most species and, in the same time, by higher fishing activities and consumption of seafood; consequently, increasing the awareness of the consumer toward a responsible seafood purchase could contribute to improve the health status of the stocks, acting on different aspects that regulate the relationship between supply and demand, affecting the entire productive chain. In conclusion, the implementation of this information needs to systematically consider all the aspects related to the fishery activities, trying to find the good compromise between social, economic and environmental sustainability, consumer's requests and his awareness. In any case, more studies are required to implement information helpful to define friendly pictures, oriented to guide the consumers towards a responsible seafood purchase.

\section{Bibliography}

Abella, A., Ratz, H.J., Charef A. (2011). Scientific, Technical and Economic Committee for Fisheries (STECF). Assessment of Mediterranean Sea stocks. Report of the STECF-11-08. Part I. EUR 24902 EN, JRC 66052. Pubblications Office of the EU, Luxembourg: 252 pp.

Blomquist, J., Bartolino, V., Waldo, S. (2015). Price Premiums for Providing Eco-labelled Seafood: Evidence from MSC-certified Cod in Sweden. Journal of Agricultural Economics, 66, 690-704.

Brécard, D., Hlaimi, B., Lucas, S., Perraudeau, Y., Salladarré, F. (2009). Determinants of demand for green products: An application to eco-label demand for fish in Europe. Ecological Economics, 69, 115-125.

Brécard, D., Lucas, S., Pichot, N., Salladarré, F. (2012). Consumer Preferences for Eco. Health and Fair Trade Labels. An Application to Seafood Product in France. Journal of Agricultural \& Food Industrial Organization, 10(1), 1-27. 
Bronnmann, J., Asche, F. (2016). The Value of Product Attributes, Brands and Private Labels: An Analysis of Frozen Seafood in Germany. Journal of Agricultural Economics, 67, 231-244.

Cardinale, M., Osio G. C. (2014). Report of the Scientific, Technical and Economic Committee for Fisheries (STECF). 2013 Assessment of Mediterranean Sea stocks. Part II. STECF-14-08. EUR 26614 EN, JRC 89860. Pubblications Office of the EU, Luxembourg: 364 pp.

Clonan, A., Holdsworth, M., Swift, J.A., Leibovici, D., Wilson, P. (2011). The dilemma of healthy eating and environmental sustainability: the case of fish. Public Health Nutrition, 15(2), 277-284.

Council Regulation (EC) No 850/98 of 30 March 1998 for the conservation of fishery resources through technical measures for the protection of juveniles of marine organisms.

Council Regulation (EC) No 27/2005 of 22 December 2004 fixing for 2005 the fishing opportunities and associated conditions for certain fish stocks and groups of fish stocks, applicable in Community waters and, for Community vessels, in waters where catch limitations are required.

Council Regulation (EC) No 51/2006 of 22 December 2005 fixing for 2006 the fishing opportunities and associated conditions for certain fish stocks and groups of fish stocks applicable in Community waters and for Community vessels, in waters where catch limitations are required, lays down quotas for 2006.

Council Regulation (EC) No 1967/2006 concerning management measures for the sustainable exploitation of fishery resources in the Mediterranean Sea.

Council Regulation (EC) No 41/2007 of 21 December 2006 fixing for 2007 the fishing opportunities and associated conditions for certain fish stocks and groups of fish stocks, applicable in Community waters and, for Community vessels, in waters where catch limitations are required.

Council Regulation (EC) No 1559/2007 of 17 December 2007 establishing a multi-annual recovery plan for bluefin tuna in the Eastern Atlantic and Mediterranean and amending Regulation (EC) No $520 / 2007$.

Davidson, K., Pan, M., Hu, W., Poerwanto, D. (2012). Consumers' willingness to pay for aquaculture fish products vs. wild-caughtseafood - a case study in hawaii. Aquaculture Economics \& Management, 16(2).

D.P.R. 1639/68. Regolamento per l'esecuzione della Legge 14 luglio 1965, n. 963, concernente la disciplina della pesca marittima.

European Market Observatory for Fisheries and Aquaculture Products (2017). EU consumer habits regarding fishery and aquaculture products.

Erwann, C. (2009). Eco-labelling: A new deal for a more durable fishery management? Ocean \& Coastal Management, 52, (5), 2009, 250-257.

Fernández-Polanco, J., Mueller Loose, S., Luna, L. (2013). Are retailers' preferences for seafood attributes predictive for consumer wants? Results from a choice experiment for seabream (Sparus aurata). Aquaculture Economics \& Management, 17(2).

Fonner, R., Sylvia, G. (2015). Willingness to Pay for Multiple Seafood Labels in a Niche Market. Marine Resource Economics, 30(1), 51-70.

Goyert, W., Sagarin, R., Annala, J. (2010). The promise and pitfalls of Marine Stewardship Council certification: Maine lobster as a case study. Marine Policy, 2010, 34, 1103-1109.

Gudmundsson, E., Wessells, C. (2000). Eco-labelling seafood for sustainable production: implications for fisheries management. Marine Resource Economics, 15, 97-113.

Gutierrez, A., Thornton, T.F. (2014). Can Consumers Understand Sustainability through Seafood EcoLabels? A U.S. and UK Case Study. Sustainability, 6, 8195-8217.

http://www.fao.org/gfcm/meetings/info/it/c/1040665/

http://www.fao.org/gfcm/reports/technicalmeetings/detail/en/c/1105308/

Hilborn, R. and C.J. Walters. 1992. Quantitative Fisheries Stock Assessment: Choice, Dynamics, and Uncertainty. Chapman Hall. New York.

International Commission for the Conservation of Atlantic Tunas (2016). Report of the 2016 Mediterranean swordfish stock assessment meeting. Casablanca, Morocco, 11-16 July 2016

Istituto di Servizi per il Mercato Agricolo Alimentare Istituto di Servizi per il Mercato Agricolo Alimentare (2011). Il pesce a tavola: percezioni e stili di consumo degli italiani.

Jaffry, S., Pickering, H., Ghulam, Y., Whitmarsh, D., Wattage, P. (2004). Consumer choices for quality and sustainability labeled seafood products in the UK. Food Policy, 29, 215-228. 
Johnston, R.J., Wessells, C.R., Donath, H., Asche, F. (2001). Measuring Consumer Preferences for Ecolabeled Seafood: An International Comparison. Journal of agricultural and resource economics, 26(1), 20-39.

Johnston, R.J., Roheim, C.A. (2006). A battle of taste and environmental convictions for ecolabeled seafood: a contingent ranking experiment. Journal of agricultural and resource economics, 31(2), 283-300.

Masahiko Ariji. (2010). Conjoint analysis of consumer preference for bluefin tuna. Fisheries Science, 76(6), 1023-1028.

McClenachan, L., Dissanayake, S.T.M., Chen, X. (2016). Fair trade fish: consumer support for broader seafood sustainability. Fish and Fisheries, 17, 825-838.

Musick, J. \& Bonfil, R (2004). Management Techniques for Elasmobranch Fisheries. FAO Fisheries Technical Pape 474, Chapter: 2, pp.6-14.

Nguyen, L.Q., Du, Q., Friedrichs, Y.V. (2010). Effectiveness of Eco-label? A study of Swedish University Students' Choice on Ecological Food (Master Thesis, Umeå School of Business, Umeå, Sweden). Retrieved from http://www.diva-portal.org/smash/get/diva2:327644/FULLTEXT01.pdf

Pérez-Ramírez, M., Almendarez-Hernández, M., Avilés-Polanco, G., Beltrán-Morales, L.F. (2015). Consumer Acceptance of Eco-Labeled Fish: A Mexican Case Study. Sustainability, 7, 4625-4642.

Pieniak, Z. Verbeke, W., Scholderer, J., Brunsø, K., Olsen, S.O. (2007). European Consumers' Use of and Trust in Information Sources About Fish. Food Qual. Prefer. 2007, 18, 1050-1063.

Potts, G.W. and Wootton, R.J. (1989). Fish reproduction: Strategies and tactics. Academic press, London. Pp 405

Relini, G., Bertand, J., Zamboni, A. (1999). Sintesi delle conoscenze sulle risorse da pesca dei fondi del Mediterraneo centrale (Italia e Corsica). Biologia Marina Mediterranea, published by SIBM, volume 6 (suppl. 1).

Richter, I. G. M. \& Klöckner, C.A. (2017). The Psychology of Sustainable Seafood Consumption: A Comprehensive Approach. Foods, 6, 86.

Rickertsen, K., Alfnes, F., Combris, P., Enderli, G., Issanchou, S., Shogren, J.F. (2017). French Consumers' Attitudes and Preferences toward Wild and Farmed Fish. Marine Resource Economics 32(1), 59-81.

Roheim, C.A., Asche, F., Santos, J.I. (2011). The elusive price premium for ecolabeled products: Evidence from seafood in the UK market. Journal of Agricultural Economics, 62, 655-668.

Salladarré, F., Brécard, D., Lucas, S. and Ollivier, P. (2016). Are French consumers ready to pay a premium for eco-labeled seafood products? A contingent valuation estimation with heterogeneous anchoring. Agricultural Economics, 47, 247-258.

Sartor, P., Mannini, A., Carlucci, R., Massaro, E., Queirolo, S., Sabatini, A., Scarcella, G., Simoni, R. (2017). Sintesi delle conoscenze di biologia, ecologia e pesca delle specie ittiche dei mari italiani. Biologia Marina Mediterranea, published by SIBM, volume 24, suppl 1.

Sciagura, C.V. (2017). Biologia e dinamica di popolazione della triglia di scoglio (Mullus surmuletus, L., 1758) nello Stretto di Sicilia. Thesis of ecobiology. Facoltà di Scienze Matematiche, Fisiche e Naturali. Corso di Laurea in Ecobiologia (Univer. La Sapienza), Academic year 2016/2017, pp. 136.

Simmonds, J., Osio, G. C., Mannini, A. (2017). Scientific, Technical and Economic Committee for Fisheries (STECF). Mediterranean assessments 2016-part 2. Report of the STECF 17-06. Part II. EUR 28359 EN, JRC 106582. Pubblications Office of the EU, Luxembourg.

Sogn-Grundvåg, G., Larsen, T. A., Young, J. A. (2014). Product Differentiation with Credence Attributes and Private Labels: The Case of Whitefish in UK Supermarkets. Journal of Agricultural Economics, 65, 368-382.

Sun, C-H.J., Chiang, F-S., Owens, M., Squires, D. (2017). Will American consumers pay more for ecofriendly labeled canned tuna? Estimating US consumer demand for canned tuna varieties using scanner data. Marine Policy, 79, 62-69.

Uchida, H., Onozaka, Y., Morita, T., Managi, S. (2014). Demand for ecolabeled seafood in the Japanese market: A conjoint analysis of the impact of information and interaction with other labels. Food Policy, 44, 68-76.

United Nations Environment Programme. (2005). The Trade and Environmental Effects of Ecolabels: Assessment and Response. Geneva, Switzerland: Tom Rotherham

Vitale, S., Giosuè, C., Biondo, F., Bono, G., Boscaino, G., Sprovieri, M., Attanasio, M. (2017). Are People Willing to Pay for Eco-Labeled Wild Seafood? An Overview. European Journal of Sustainable Development, 6, 3, 20-28. 
World Business Council for Sustainable Development. (2008). WBCSD, Sustainable Consumption: Facts and Trends. Geneva, Washington DC, Brussels.

Xu, P., Zeng, Y., Fong, Q., Lone, T., Liu, Y. (2012). Chinese consumers' willingness to pay for green- and eco-labeled seafood. Food Control, 28, 74-82.

Zhou, G., Hu, W., Huang, W. (2016). Are consumers willing to pay more for sustainable products? A study of eco-labeled tuna steak. Sustainability, 8(5), 494. 
Appendix. Synoptic table of the seafood species related to the four items $\left(S A, L_{50 \%} / W_{50 \%}, M S\right.$ and $\left.R P\right)$ chosen among the sustainable criteria

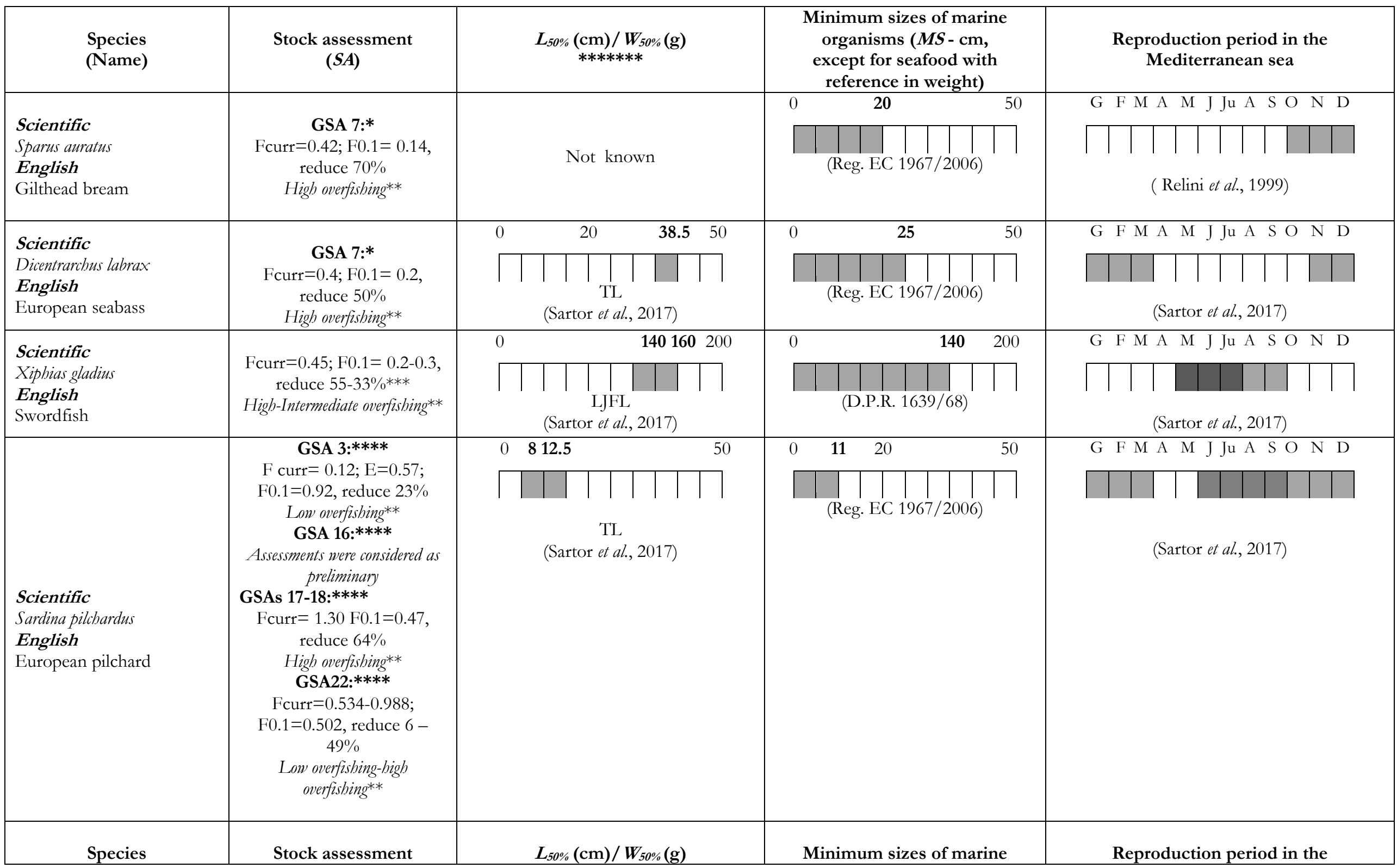




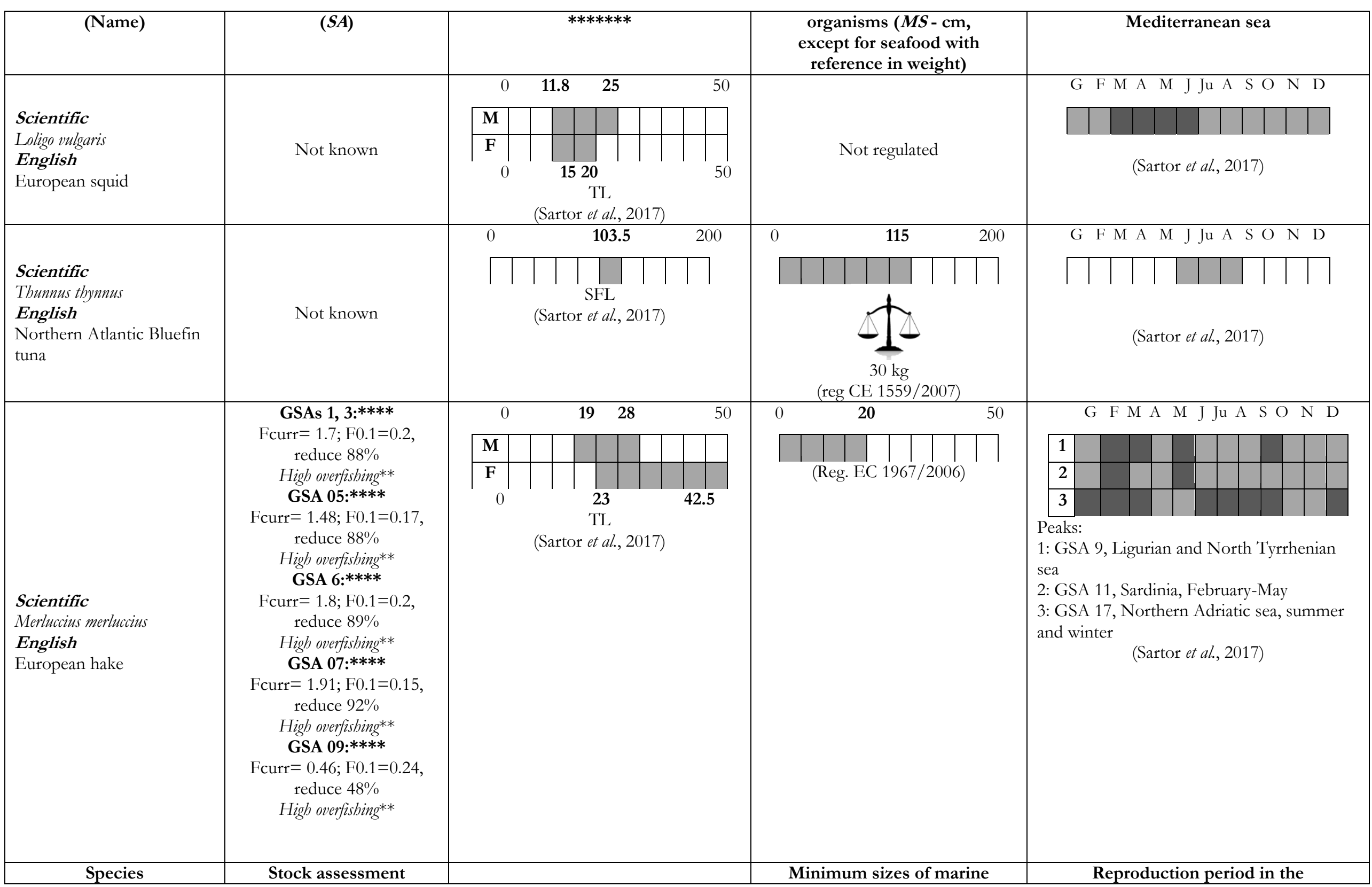




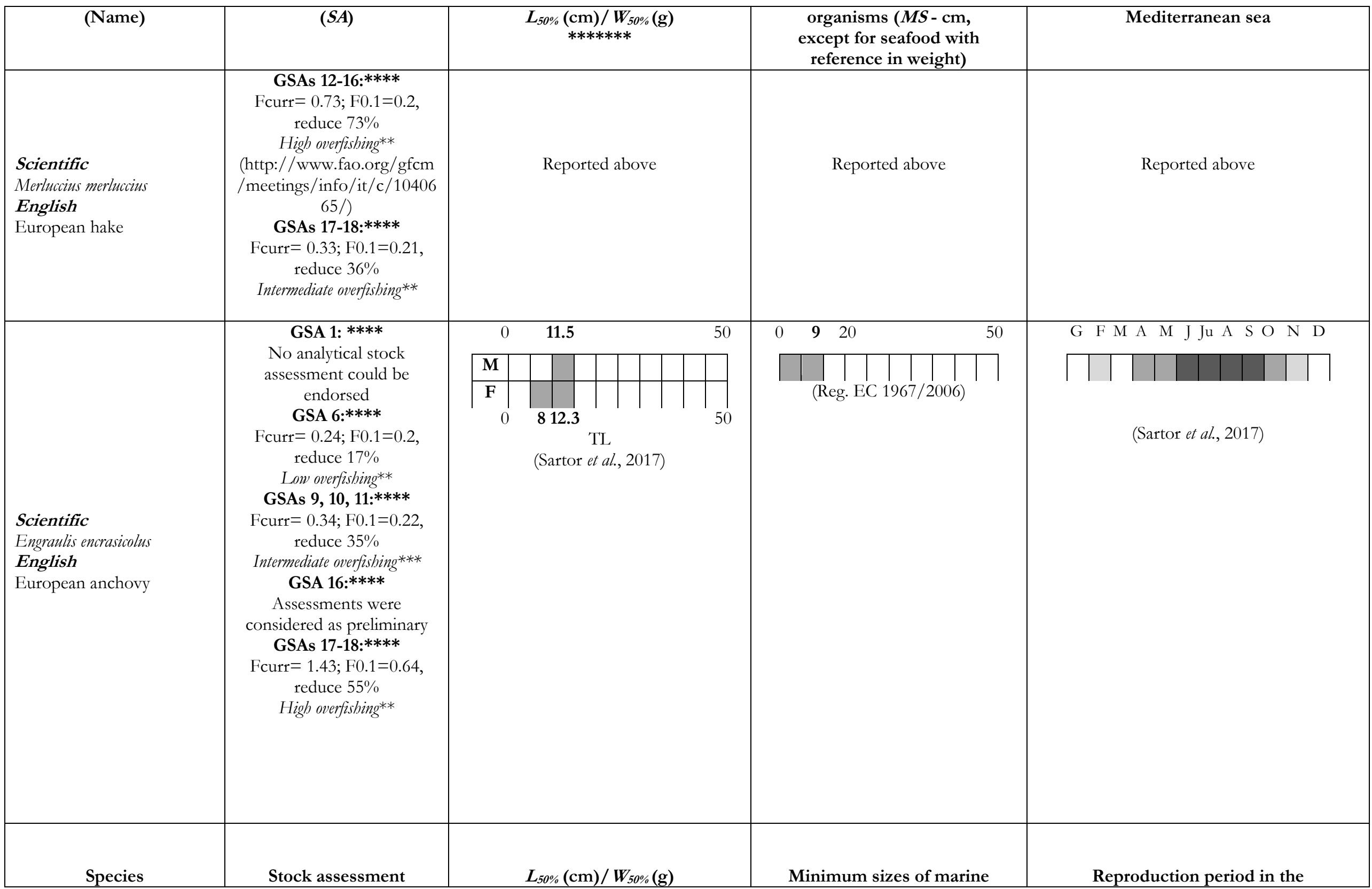




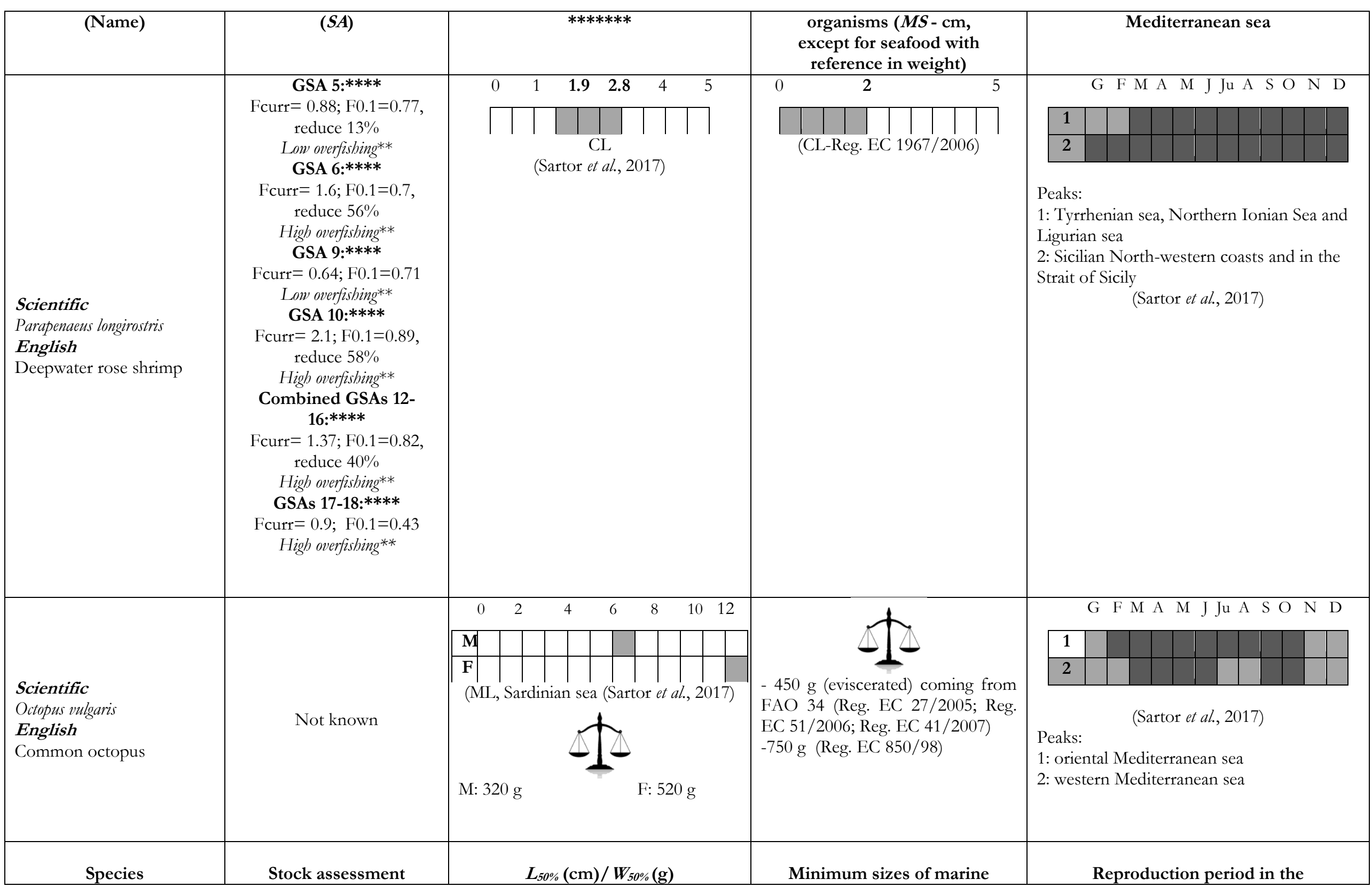




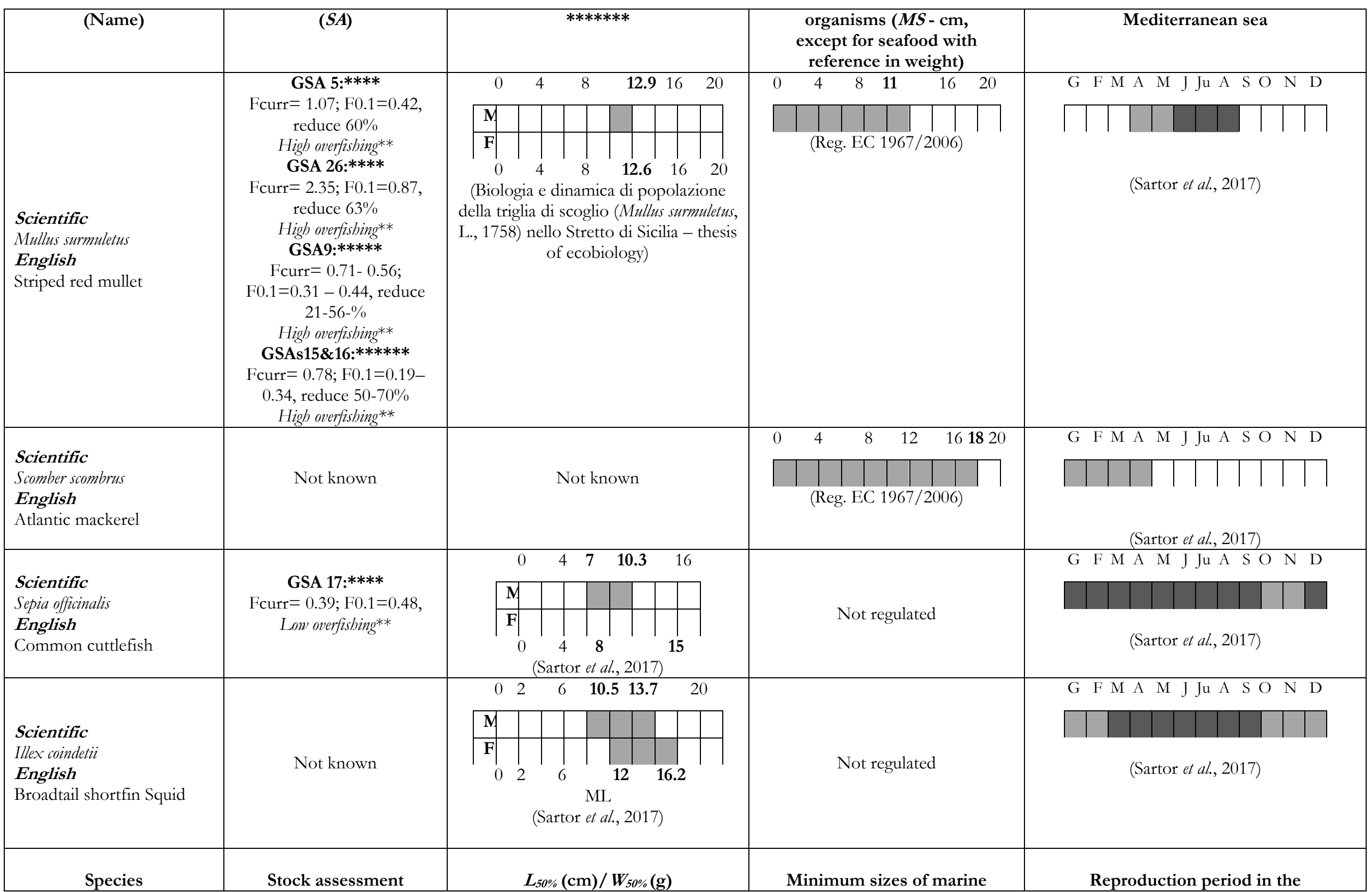




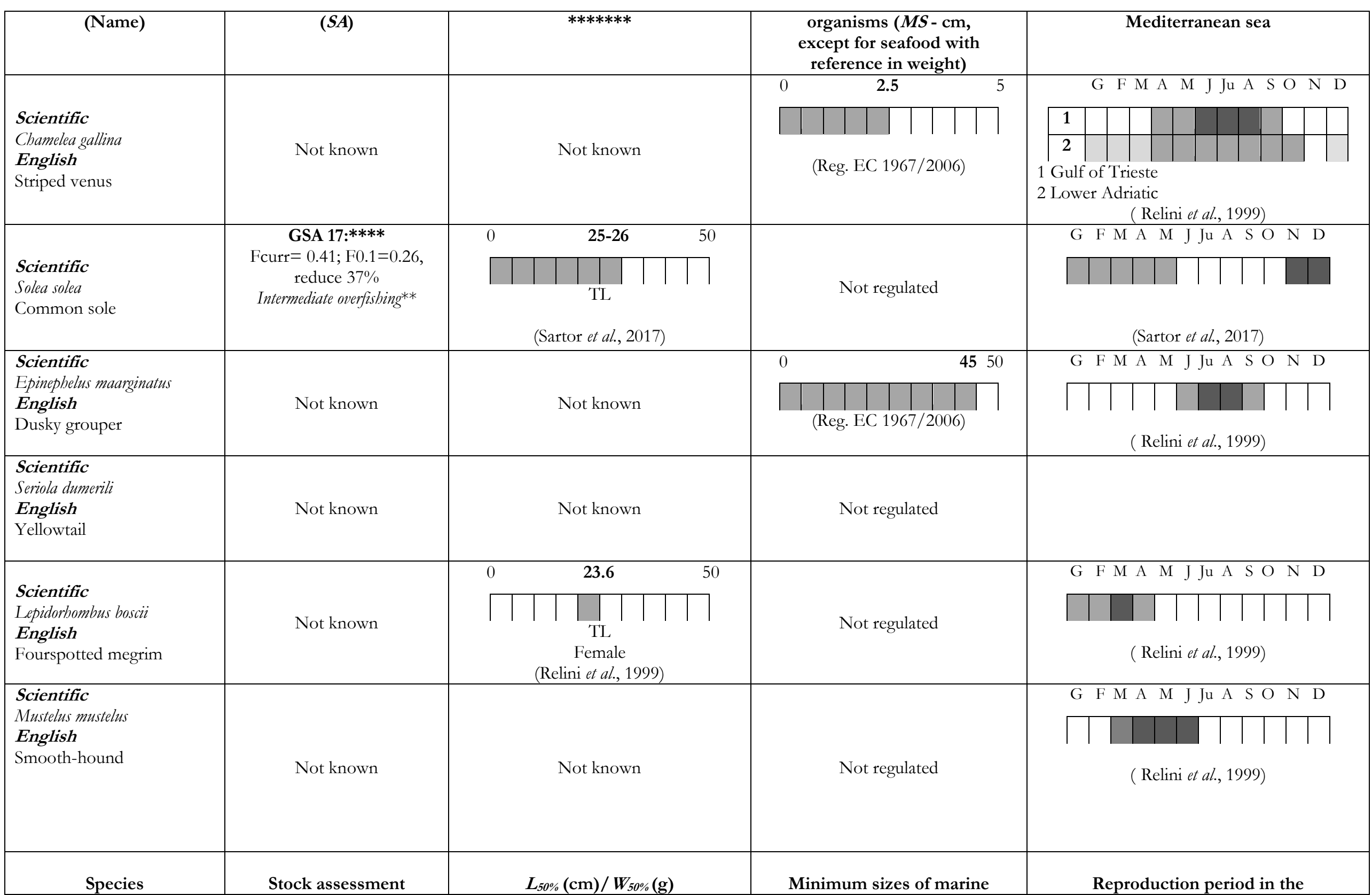




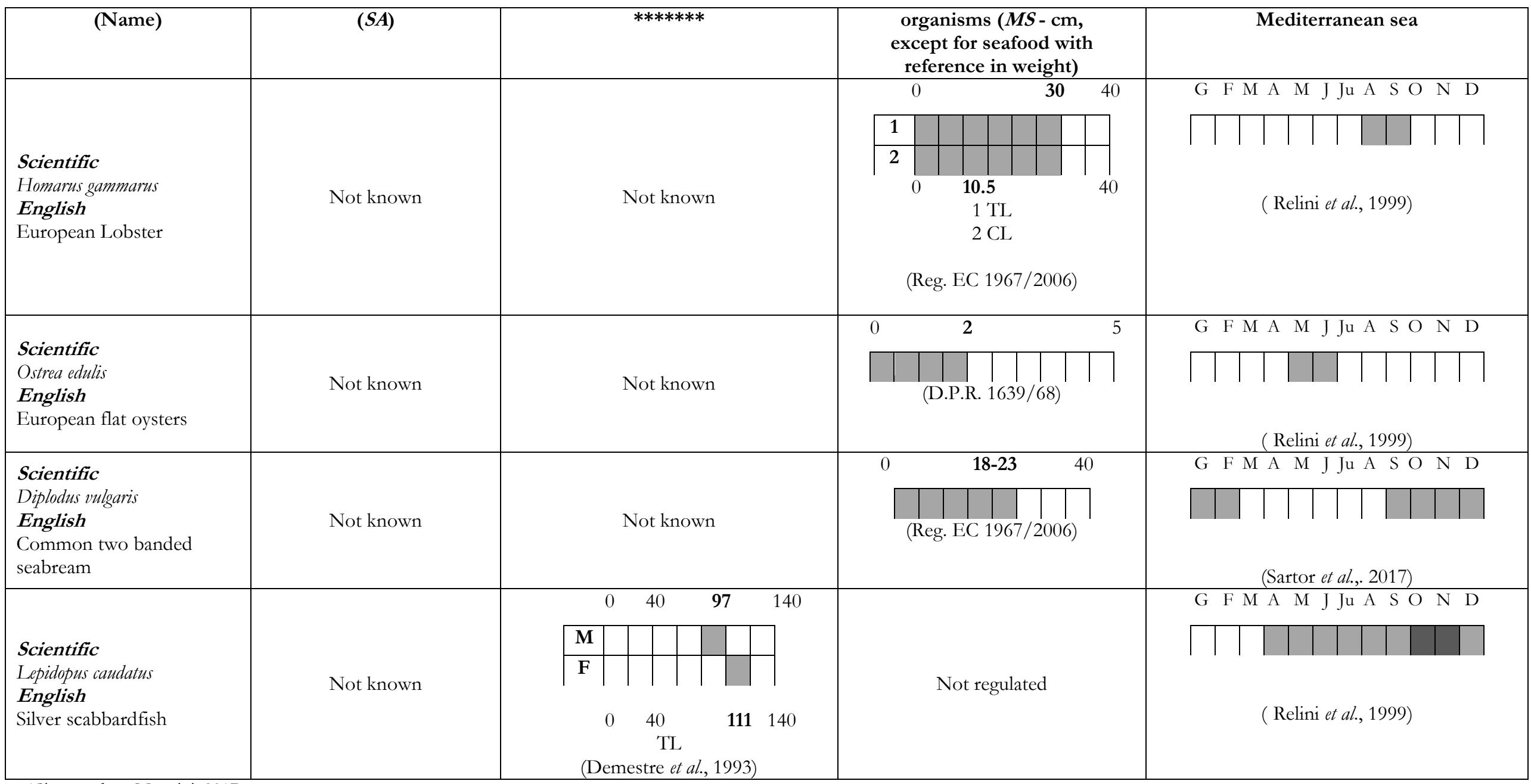

*Simmonds \& Mannini, 2017;

**http://www.fao.org/gfcm/meetings/info/it/c/1040665/;

*** International Commission for the Conservation of Atlantic Tunas, 2016

****http://www.fao.org/gfcm/reports/technicalmeetings/detail/en/c/1105308/;

*****Abella et al., 2011

******Cardinale\&Osio, 2014

$* * * * * * * T L=$ Total Length; CL $=$ Carapace Length $; \mathrm{LJFL}=$ Lower Jaw-Fork Length; SFL=Straight Fork Length 